\title{
3D NYOMTATOTT RÉTEGEK KÖZÖTTI ADHÉZIÓ KÍSÉRLETI VIZSGÁLATA
}

\author{
Magyarics Norbert ${ }^{a}$, Safranyik Ferenc $^{b^{*}}$, Andó Mátyás ${ }^{b}$ \\ ${ }^{a}$ ELTE Informatikai, Kar, Savaria Múszaki Intézet, Gépészmérnöki BSc, 3. évf. \\ ${ }^{b}$ ELTE Informatikai, Kar, Savaria Müszaki Intézet, egyetemi docens
}

\begin{abstract}
ABSZTRAKT
A gyors prototípusgyártással kialakított alkatrészek gyakorlati alkalmazása alapján azok réteges felépítése befolyásolja mechanikai tulajdonságaikat. Ahhoz, hogy a mûszaki számítások során figyelembe tudjuk venni ezt a heterogén felépítést, elengedhetetlen a rétegekre-, és azok összekapcsolódására jellemző mechanikai tulajdonságok ismerete. A rétegek közt kialakuló adhézió kísérleti vizsgálatához különböző, szabványos próbatestek vizsgálata után egyedi mérô készüléket terveztünk. A fejlesztéshez végeselem analízist alkalmaztunk a számunkra ideális kialakítás érdekében. A készülék múködôképességét a kontúrvonalszám teherbírásra gyakorolt hatását vizsgáló mintakísérlettel bizonyítottuk. Ez alapján megállapítottuk a rétegek közti adhézió nagyságát, illetve megvizsgáltuk, hogy adott kitöltési mód esetén hogyan kell figyelembe venni a próbatest keresztmetszetét.
\end{abstract}

Kulcsszavak: adhézió, FDM, FFF, nyírás

\section{Bevezetés}

A 21. században népszerúvé és elérhetôvé vált a 3D nyomtatás a végfelhasználók számára is. Kutatások, korai projektek már az 1980-as évektól léteznek a témában, de a napjainkban elterjedt a rétegenként felépítő, ráolvasztásos elven múködő, úgynevezett FDM (Fused Deposition Modeling) eljárást 1992-ben a Stratasys cég fejlesztette ki [1]. Az eljárás gyors prototípusgyártásra, egyedi alkatrészek pótlására, vagy akár dísztárgyak készítésére is alkalmazható, már otthoni körülmények között is [2]. Magyarországon 2010-2012-tôl lehet otthoni, elérhető árú 3D FDM polimer nyomtatókat vásárolni.

Az FDM technológia lényegében rétegek egymáshoz kapcsolásából épít fel tárgyakat, néhány tized milliméteres rétegvastagságokkal. A hơre lágyuló polimer alapanyag megolvad és nyomás hatására kiáramlik egy fúvókán. A megolvadt anyagból, ömledékból a gép vonalakat húz a fúvóka alatti síkra, legyen az a tárgyasztal vagy egy korábbi réteg. Az egy síkba húzott vonalak összessége alkot egy réteget. Az egymás mellé húzott vonalak kapcsolódnak - részleges megolvadással - a korábbi vonalakhoz, illetve az alattuk található réteghez, melyek között adhéziós kapcsolat alakul ki [3]. Mind a technológia, mind az alkatrészek múszaki jellemzôi számos kérdést vetnek fel.

Az FDM technológiával gyártott alkatrészek heterogén szerkezeti felépítése miatt különbözô igénybevételek esetén nem alkalmazhatók megfelelő pontossággal a klasszikus tönkremeneteli elméletek. A kompozitszerkezetek mechanikai tulajdonságainak becslésére alkalmazott homogenizációs eljárások, mint például a Halpin-Tsai egyenlet [4], sem lehetnek célravezetôek, mivel azokkal a speciális tönkremeneteli folyamatok (mint a rétegek szétválása) nem kezelhetô. A modern, numerikus eljárásokkal (mint a végeselem módszer) a réteges testek speciális tönkremeneteli folyamatai jól közelíthetőek, amit hagyományos kompozitok esetén már számos kutató bizonyított [5]. Ebból kiindulva a munkánk célja az FDM eljárással gyártott alkatrészek tönkremenetelének olyan numerikus modellezése,

(C) ELTE, Informatikai Kar, Savaria Múszaki Intézet, 2021

*Kapcsolattartó: Safranyik Ferenc, sf@inf.elte.hu

https://doi.org/10.37775/EIS.2021.1.4 


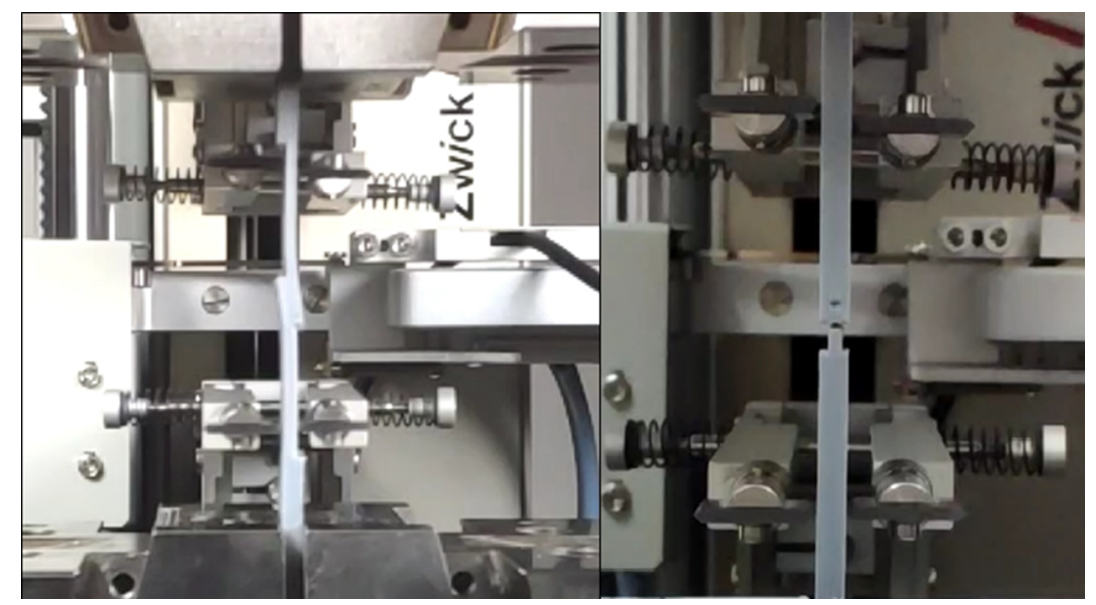

1. ábra: Az átlapolt próbatestek nyírási vizsgálata

amely során a tárgyat felépítő rétegek szétválnak. Elsô lépésként a különbözô technológiai paraméterek, rétegek közötti adhézióra gyakorolt hatásának kísérleti vizsgálatát végeztük el. Ehhez a Savaria Múszaki Intézetben található univerzális anyagvizsgáló berendezéshez egy olyan nyírókészüléket terveztünk, amellyel a nyomtatott alkatrészek rétegei közötti adhézió vizsgálható, majd mérések sorozatával feltérképeztük a nyomtatási paraméterek és a rétegeket összetartó erő közötti kapcsolatot.

\section{Elökísérletek}

Az adhézió vizsgálatához készített próbatestek anyaga PLA (Gembird 3DP-PLA1.75-01-GR). A 3D nyomtatást egy Creality Ender 5 típusú berendezésen végeztük, amelyen a nyomtatási minôséget befolyásoló módosítások nem történtek a gyári állapothoz képest. A nyomtatási beállítások a következốk voltak: $205{ }^{\circ} \mathrm{C}$ fúvóka hômérséklet, $60{ }^{\circ} \mathrm{C}$ asztal hômérséklet, $25 \%$ belsô kitöltés, $0,2 \mathrm{~mm}$ rétegvastagság, $0,3 \mathrm{~mm}$ vonalvastagság.

Elókísérletek során megvizsgáltunk többféle szabványos, illetve módosított geometriákat is. Ezen kialakítások az anyagvizsgáló berendezésben húzó igénybevétellel hoznak létre nyírást. Egyszeresen nyírt (ASTM D906 [6]) és kétszeresen nyírt (ASTM D3528 [7]) geometriák esetén is azt tapasztaltuk, hogy nem az elméleti nyírási síkban mentek tönkre a 3D nyomtatott próbatestek (1. ábra).

A kísérleteket Zwick Roell Z100 típusú univerzális anyagvizsgáló berendezésen végeztük, $3 \mathrm{~mm} / \mathrm{min}$ elmozdulási sebességgel. A berendezésen található erômérô cella mérési hibája 200-1 $000 \mathrm{~N}$ mért érték között 1\%, $1000 \mathrm{~N}$ felett pedig 0,5\%. A tönkremenetel oka, hogy az adhézió és az alapanyag szilárdsága hasonló nagyságrendú, ezért az alapanyag mechanikai tulajdonságai határozzák meg a tönkremenetel módját [8], összetett igénybevétel miatt. Ezek a mérési megoldások akkor tudják a nyírás jellegú tönkrementtel biztosítani, ha az adhézió kisebb mértékú az anyag szilárdságához képest (pl.: átlapolt, ragasztott kötések esetén).

További elôkísérletet végeztünk az ASTM B831 [9] szabvány alapján készült próbatesteken, amely elsôsorban homogén lemezek nyíró vizsgálatára alkalmas. A kísérlet során azt tapasztaltuk, hogy a próbatestek nem a tervezett tönkremeneteli zónában nyíródtak el. A jellemzó tönkremenetel a horony végéból kiinduló, a húzás irányára merôleges repedés volt (2. ábra). Ebben az esetben a tönkremenetel oka a polimerek fémekhez viszonyított alacsony rugalmassági modulusában keresendő. Múanyagok esetén jóval nagyobb deformáció keletkezik a szabványos próbatesten, ugyanilyen geometriájú fém próbatesthez képest, ezért a hajlítás dominánssá válik a kísérlet során. Így a próbatesten nem nyírás jellegú tönkremenetel tapasztalható.

Az előzetes mérésekból azt a következtetés vontuk le, hogy az általunk keresett tönkremeneteli módhoz - vagyis a rétegek közötti síkon történő nyírás általi tönkremenetelhez - valószínúleg nem lehetséges olyan geometriát kialakítani a választott alapanyagból, ami ebben a vizsgálati rendszerben 


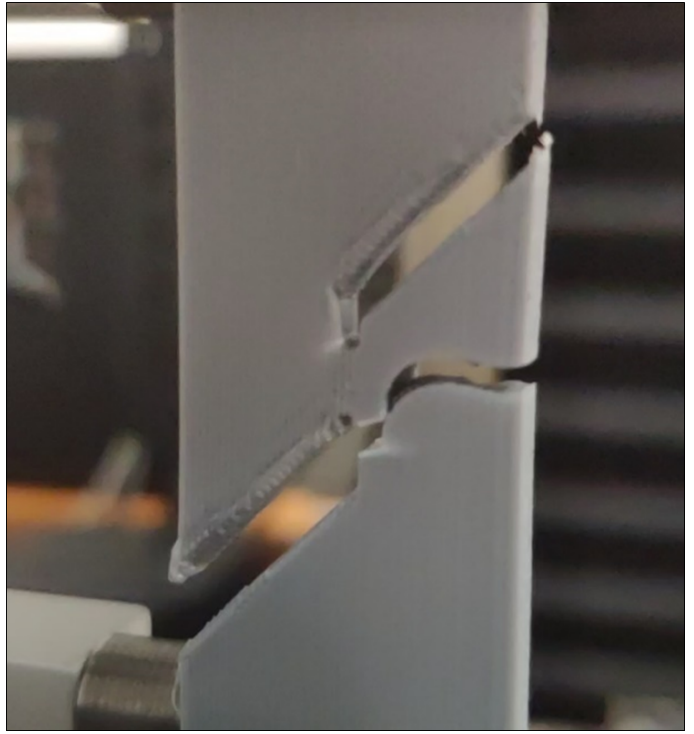

2. ábra: Az ASTM B831 alapú próbatest tönkremenetele

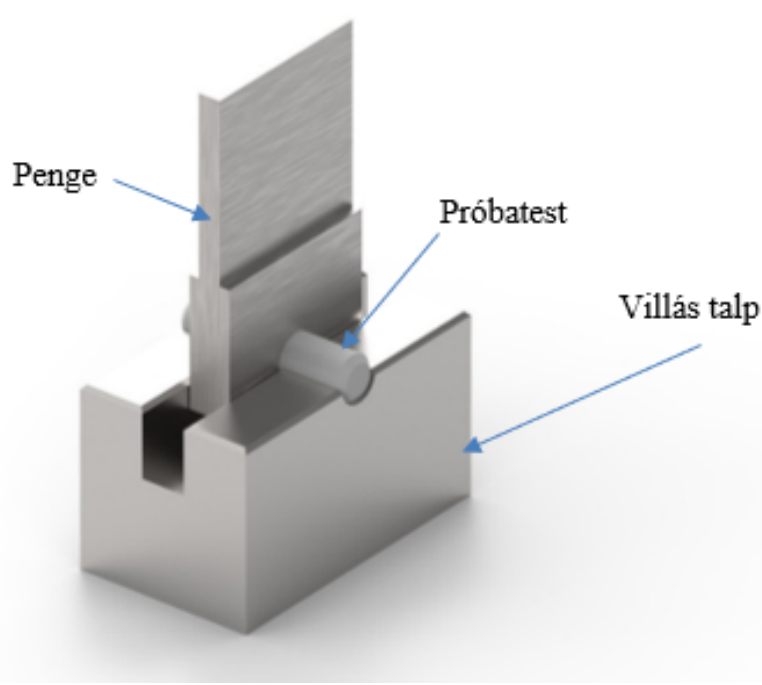

3. ábra: A nyírókészülék

biztosítaná a megfelelő feszültségi állapotot és tönkremenetelt. Az elvégzett kísérletek alapján elvetettük a húzáson alapúló vizsgálati elrendezést. A továbbiakban bemutatjuk az új készülék tervezését, amellyel várhatóan elérhetô lesz a kívánt tönkremeneteli mód megbízható mérése.

\section{Optimális nyírási környezet kialakítása és tesztelése}

A rendelkezésre álló anyagvizsgáló berendezés felszerelhető egyedi készülékekkel, mérôberendezésekkel is, de új készülék tervezésével párhuzamosan a hozzá tartozó próbatestet is szükséges megtervezni. A folyamathoz a MIL-STD-1312-13 [10] szabvány nyújtott segítséget, ami a kötőelemek nyíróvizsgálatával foglalkozik és villás nyírókészülék kialakítást mutat be (3. ábra). A készülék kialakításakor fontos tényezốk voltak az erômérő cella pontossága, a csatlakozó felek között elérhető legnagyobb távolság, a már meglévô egyedi készülékek rögzítési módjának újra-felhasználása, valamint a készülék legyártásához rendelkezésre álló technológiák.

A penge és a villás talp között javasolt hézagot a mi vizsgálati esetünkre optimalizáltuk végeselem analízist használva. A végeselem analízishez az Ansys szoftvercsomag 2019 R1 verzióját használtuk, az Ansys Workbench Static Structural moduljában dolgoztunk. A végeselem analízis során a szerkezet szimmetriáját kihasználva a szimmetria sík mentén kettévágott modellt alkalmaztunk, az
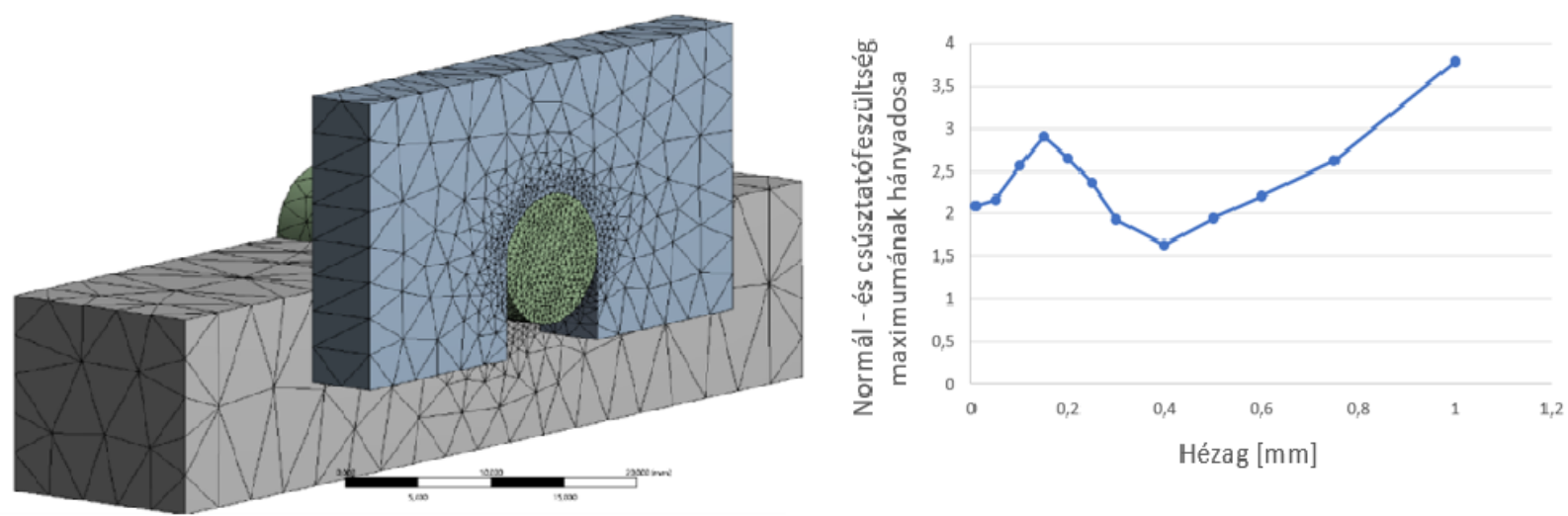

4. ábra: a) A végeselem analízis során alkalmazott háló; b) A maximális normál - és csúsztató feszültség hányadosa a nyírási síkban a hézag függvényében 
analízis szempontjából elhanyagolható további részek eltávolításával (4/a ábra). A vizsgált hézag 0-1 mm között 12 lépcsóben került kiértékelésre. 0 és $1 \mathrm{~mm}$ közötti hézagok hatását vizsgáltuk meg a próbatestben ébredô feszültségekre vonatkozóan. A legmegfelelóbb hézag az, amelynél a normálés csúsztatófeszültségek aránya a legkisebb (4/b ábra), hiszen ez áll a legközelebb a tiszta nyíráshoz. Az analízis eredménye azt mutatja, hogy túlságosan kicsi rés esetén jelentôs a felületi feszültség hatása, ezért 0,4 mm-es oldalankénti hézagot érdemes létrehozni a készülékben. A készülék alsó felét egy, már meglévő hajlítókészülék rögzítésére szolgáló sínbe helyezzük, míg a felsô felét a húzáshoz alkalmazott szorítókkal fogtuk meg (5. ábra).

\section{Laboratóriumi vizsgálatok}

A rétegek nyomtatása során először az aktuális réteg (a 6. ábrán színessel kiemelt rész) kontúrját készíti el a berendezés, a szelet külsố határolóvonalait. Ha egynél több kontúrvonal van, általában kívülrôl a második vonal készül el először, majd ezután a külső kontúrvonal (a 6. ábrán piros színnel). A külső kontúrvonal után visszatér a fej a test belsejébe, folytatja a hátralévő kontúrvonalak létrehozását (a 6. ábrán zöld színnel). Miután a kontúrvonalak elkészültek, a berendezés a belsô kitöltést készíti el (a 6. ábrán narancssárga színnel), minden rétegben csak párhuzamos vonalak készülnek, rétegenként felváltva $90^{\circ}$ bezárt szöggel. 0 kontúrvonal esetén csak kitöltés típusú vonalak készülnek el. A vizsgálat során alkalmazott belsô kitöltés egy rétegen belül csak egymással párhuzamos vonalakat tartalmaz, az előző rétegre merőlegesen elhelyezve azokat.

A készülék tesztelése során megállapítottuk, hogy a névleges méretre készített próbatestek (7/a ábra) a gyártástechnológia sajátosságai miatt megszorulnak a kialakított horonyban, ami negatívan hat a mérés pontosságára. A próbatestek nyomtatási paramétereit úgy változtattuk, hogy a próbatest mérete 9,9-10 mm közötti legyen. Továbbá megállapítottuk, hogy a kialakítás megfelelő, mert a rétegek közötti sík mentén közel tiszta nyírás történt (7/b ábra), vagyis a próbatestek az elvárásoknak megfelelően mentek tönkre. A vizsgálatok során a próbatestek terhelhetősége $500 \mathrm{~N}$ és $3300 \mathrm{~N}$ között változott, míg az erômérố cella hibája 5-16,5 N közötti, vagyis elhanyagolható. Ez alapján az mért erố megfelelóen dokumentálható, amelyet a 8. ábrán látható ismételhetőség is bizonyít. Az új rendszerrel a kontúrvonalak számának nyírószilárdságra gyakorolt hatását vizsgáltuk a továbbiakban. A kontúrvonalak számát 1 és 9 között vizsgáltuk meg, 25\% belsô kitöltés mellett.

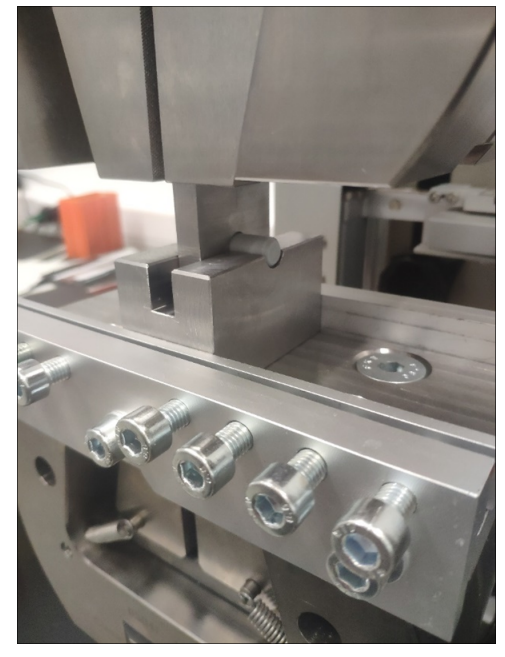

5. ábra: A nyírókészülékbe befogott próbatest nyírás előtt

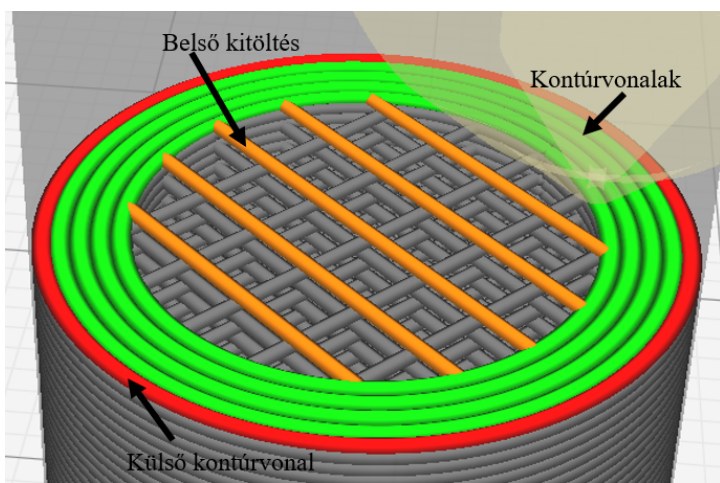

6. ábra: A nyomtatott test keresztmetszete a szeletelő programban 

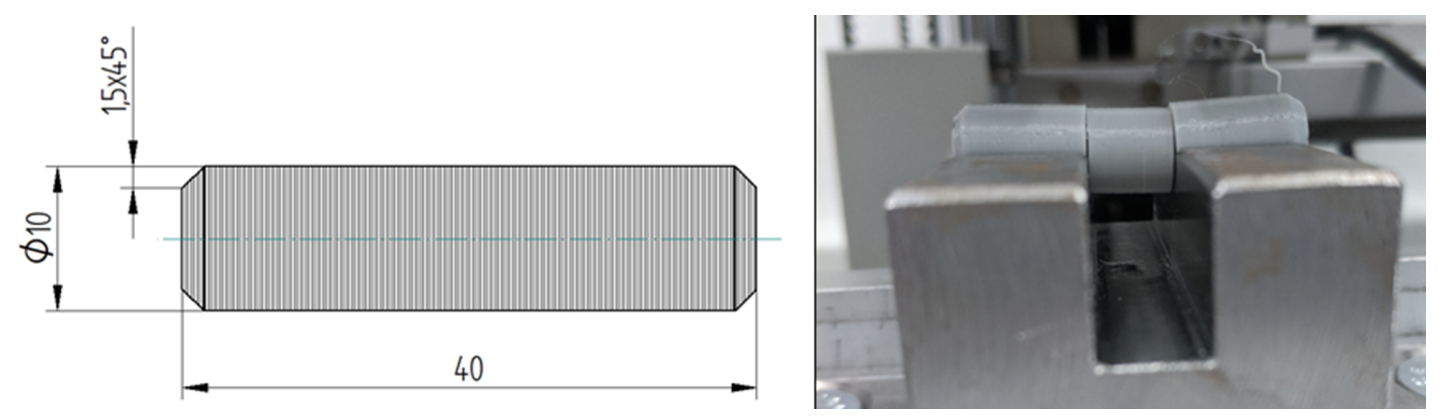

7. ábra: a) A próbatest és a rétegek iránya; b) A próbatest tönkremenetele

\section{Eredmények}

Az elvégzett mérések eredményeit a 9. ábra foglalja össze, ahol a kontúrvonalak számának függvényében látható a tönkremenetelhez szükséges erô. 0 kontúrvonallal rendelkezô próbatestek mérése bizonytalan értékeket eredményezett. A grafikonon az azonos kontúrvonalszámmal gyártott próbatesteken mért maximális erôhöz tartozó átlag szerepel, 95,4\%-os valószínúséghez tartozó hibasávval. A vizsgált tartományban lineáris összefüggés van a kontúrvonalak száma és a teherbírás között, azonban mivel egyre csökken a kontúrvonalakkal hozzáadott felület, ezért szélesebb intervallumban vizsgálódva várhatóan telítődés jellegú függvénykapcsolatot figyelhetünk meg. A legnagyobb szórás $\pm 20 \%( \pm 2 \sigma)$, ami a próbatest gyártástechnológiájából adódik.

\section{6. Értékelés}

Elemeztük az aktív felület hatását a teljes próbatest teherbírására. A töret felületeit megvizsgálva megállapítottuk, hogy mivel az alkalmazott kitöltési mód egy rétegben csak $x+45^{\circ}$, míg a következő rétegben $x-45^{\circ}$ irányban generál kitöltést, ezáltal mindössze a vonalak kereszteződésénél van kapcsolat a kitöltés vonalainak az átfedése között (10. ábra). Az egymás felett elhelyezkedő vonalak között nem alakul ki adhézió, ezért az aktív felületet számító képletben egy módosító tényezôt alkalmaztunk, ahol $d=1,2 \mathrm{~mm}$ (a belsố kitöltésben mérhetô vonalak közötti távolság, 10. ábra). A számításhoz használt összefüggés további paraméterei: $r=4,95 \mathrm{~mm}$ (próbatest külső sugara), $v=0,3 \mathrm{~mm}$ (kontúrvonal vastagsága), $n$ pedig a kontúrvonalak száma. Ezek felhasználásával az aktív felület:

$$
A=A_{\text {kontúr }}+A_{\text {kitöltés }}=\left[r^{2} \pi-(r-v n)^{2} \pi\right]+\left[0,25 \frac{v}{d}(r-v n)^{2} \pi\right] .
$$

Az összefüggés elsô tagja a teljesen kitöltött külsô gyưrú területe, míg a második a rácsvonalak területe 25\%-os kitöltöttség esetén (eredmények a 11. ábrán).

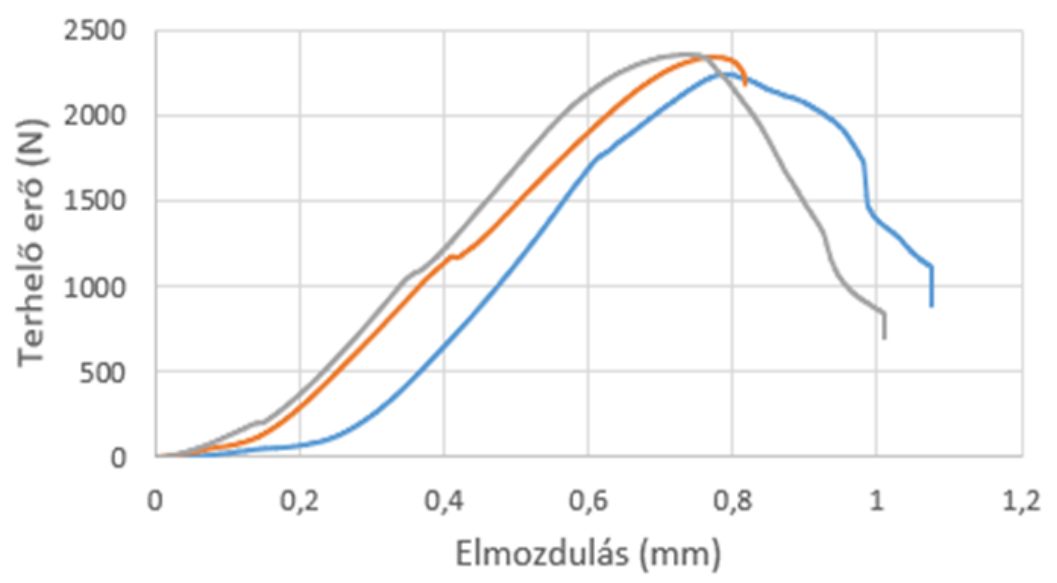

8. ábra: A 6 kontúrvonallal gyártott próbatestek tönkremeneteli diagramja 


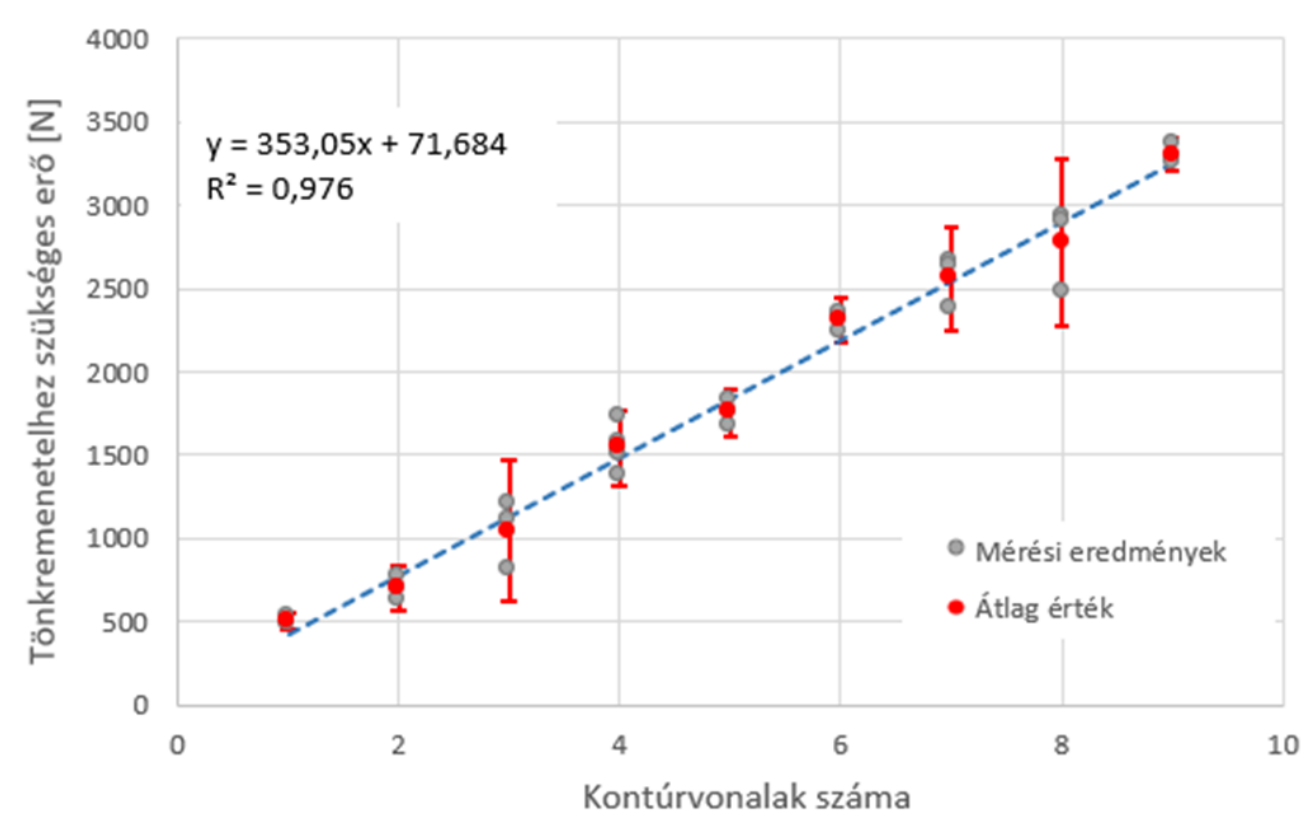

9. ábra: A kontúrvonalak számának hatása a nyírószilárdságra

Az adhéziót az alábbi közelítő összefüggéssel számítottuk, amelyben $F$ a tönkremenetelkor mért erô, $A$ pedig az aktív felület:

$$
\tau=\frac{F}{2 A} .
$$

Az aktív felület figyelembevételével a korábbi kutatások és gyártói adatokkal jól egyezô [7], 16$26 \mathrm{MPa}$ átlagos értékú adhéziót kaptunk. Mindazonáltal az is belátható, hogy bár az aktív felület adott, alacsony kontúrvonalszám esetén a belsố kitöltés által hozzáadott aktív felület 5 kontúrnál még $5 \%$ felett van, így hatása a mérési eredményekben jobban megjelenik, amelyet a 12. ábrán látható $A_{\text {kitöltés }} / A_{\text {kontúr }}$ arány jól jellemez. Az 5 határ-kontúrvonalszám alatt jelentôs a belsô kitöltés a kontúrvonalakkal hozzáadott felülethez képest, míg e felett annak hatása gyakorlatilag elhanyagolható, az adhézió értéke gyakorlatilag állandó, 24-25 MPa. A belsô kitöltés fajlagos terhelhetősége alacsonyabb, mint a kontúrvonalaké, ezért emelkedik kis mértékben az adhézió 6 kontúrig (13. ábra). A pontos hatásmechnizmus megállapításához további mérések és szimulációk szükségesek.

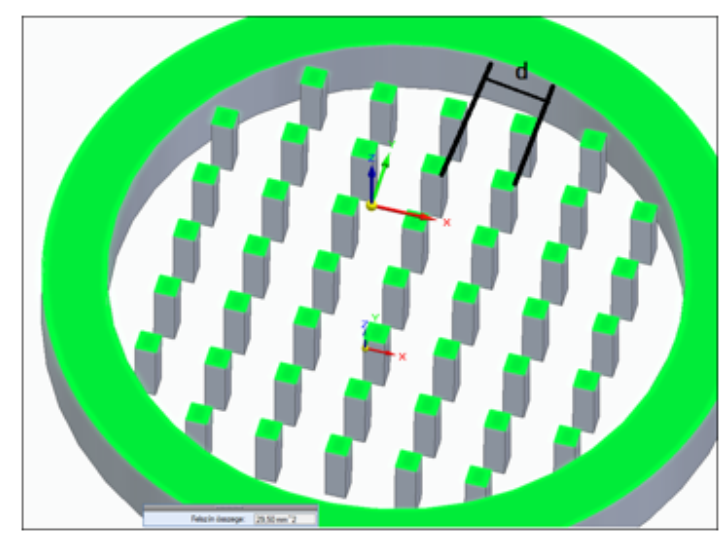

10. ábra: Teherviselő aktív felületek helyzete

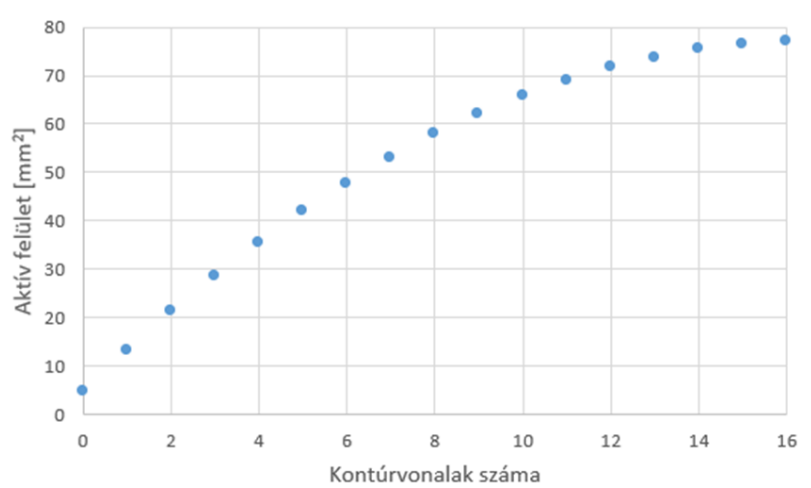

11. ábra: Az aktív felület a kontúrvonalak számának függvényében 


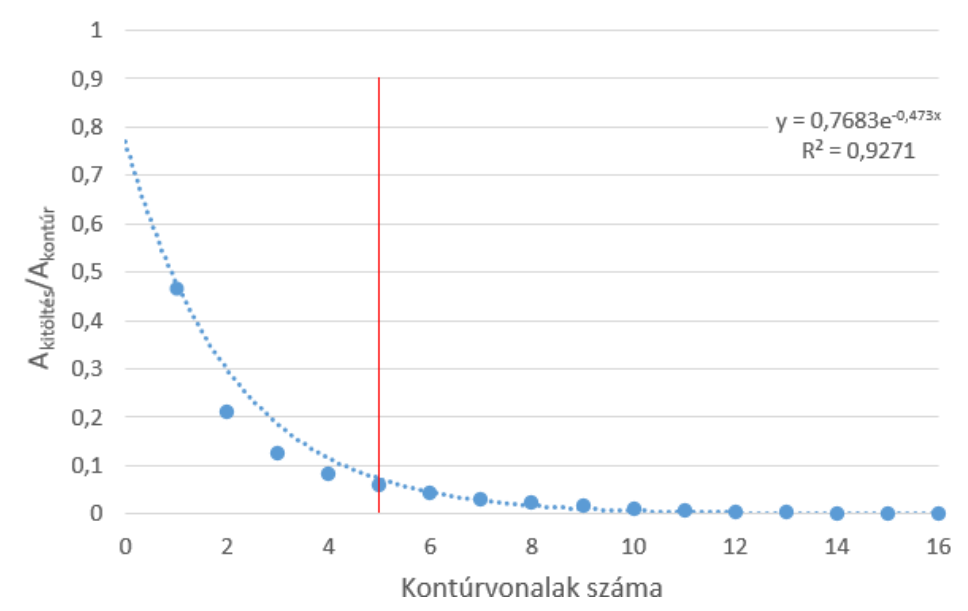

12. ábra: Az aktív felületben résztvevô felületek aránya a kontúrvonalszám függvényében

\section{7. Összefoglalás}

A kutatás során olyan vizsgálati módot kerestünk, amellyel gyors-prototípusgyártási technológiával (FDM) készített próbatestek nyírása megbízhatóan és pontosan vizsgálható. A vonatkozó szakirodalom áttekintése alapján megállapítottuk, hogy egyszerú próbatest segítségével, távolodó befogásban végzett vizsgálatot több szabvány meghatároz, valamint egyedi készülékkel történô, közeledő pofákkal elvégzett nyíráshoz is található szabványos ajánlás.

Az elókísérletek során több átlapolt, ragasztott kötésre kialakított adhéziós kapcsolat teherbírását vizsgáló próbatest geometriát gyártottunk le és vizsgáltunk meg. Az eredmények azt mutatták, hogy az átlapolt kötés nyíróvizsgálata csak olyan esetben alkalmazható, ahol a kötés szilárdsága jelentősen elmarad az adhézió által kötött anyagok szakítószilárdságától. További probléma, hogy polimerek esetén a kisebb rugalmassági modulusz miatt a deformáció nagyobb, így a hajlítási komponens jelentôssé válik aszimmetrikus próbatestek esetén. Megvizsgáltunk homogén fémes anyagok nyírására alkalmas próbatest geometriát is, de a tönkremenetel ebben az esetben sem volt megfelelő, mivel a polimerek alacsony rugalmassági modulusa jelentősen befolyásolta a fellépő hajlítást. A tapasztalatok alapján megállapítottuk, hogy ez az elrendezés nem megfelelő a célunkhoz, ezért kifejezetten a nyíró igénybevétel létrehozására alkalmas készülék tervezése mellett döntöttünk.

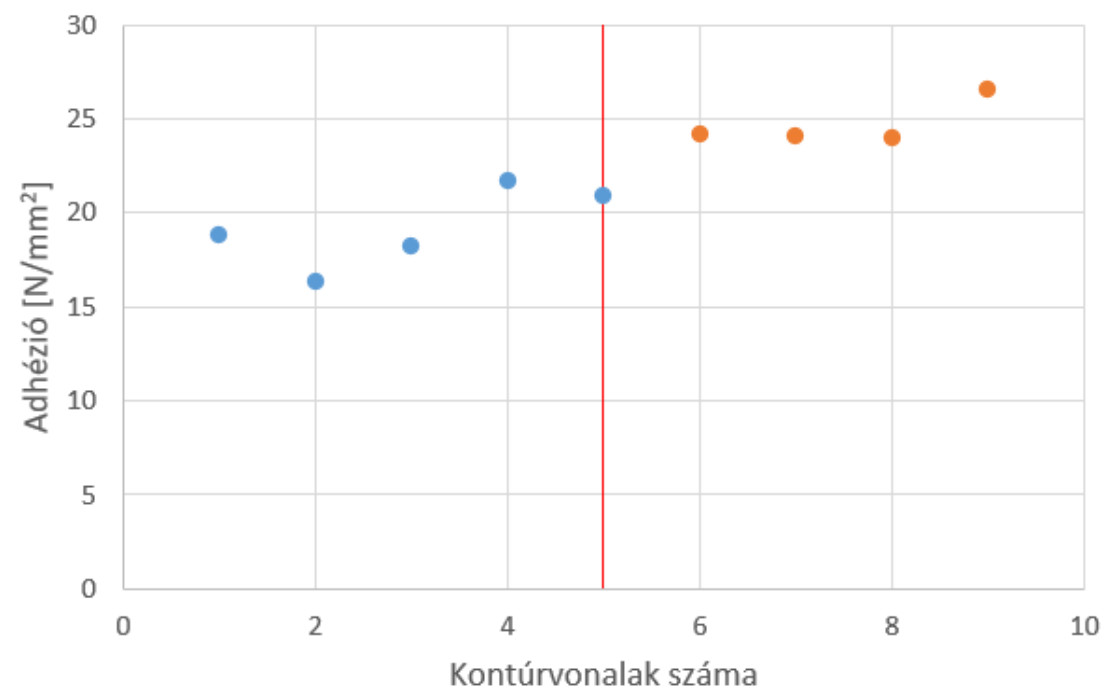

13. ábra: Kompenzált aktív felületre módosított adhézió a kontúrvonalak számának függvényében 
A tervezéshez felhasználtuk a MIL-STD-1213-13 szabványt [9], illetve adaptáltuk a rendelkezésre álló gyártástechnológiára, felhasználási környezetre. A legfontosabb lépés a penge és a villás talp közötti hézag méretének megállapítása volt, melyhez végeselem analízist alkalmaztunk. Megállapítottuk, hogy a kialakított rendszer a kívánt tönkremenetelt eredményezi. Célunknak megfelelóen, több tucat próbatesten a nyírási sík tisztán kivehető volt, valamint mind egy-egy sík mentén váltak több részre.

Az új rendszerben vizsgáltuk a kontúrvonalak hatását a nyírószilárdságra, 1-9 közötti kontúrvonallal rendelkező próbatestek esetén. A megfelelő aktív felület számítási módszer kidolgozása után megállapítottuk, hogy a 3D nyomtatott alkatrész rétegei közötti adhézió a PLA anyagnál nagyságrendileg 14-24 MPa közé adódik. Fontos megjegyezni, hogy alacsony kontúrvonalszám esetén a próbatestek kisebb szilárdságot mutattak. Elegendően nagy kontúrszám felett az adhézió viszont lényegesen nem változik - telítődést mutat $23 \mathrm{MPa}$ érték körül.

\section{Köszönetnyilvánítás}

Az Innovációs és Technológiai Minisztérium ÚNKP-20-4 kódszámú Új Nemzeti Kiválóság Programjának a Nemzeti Kutatási, Fejlesztési és Innovációs Alapból finanszírozott szakmai támogatásával készült.

\section{Irodalomjegyzék}

[1] F.B. Prinz, C.L. Atwood, R.F. Aubin, JTEC/WTEC panel report on rapid prototyping in Europe and Japan. Volume 1: Analytical chapters, United States: N. p., 1997. Web, url

[2] T. Rayna, L. Striukova, From rapid prototyping to home fabrication: How 3D printing is changing business model innovation, Technological Forecasting and Social Change 102, 2016, pp. 214-224, CrossRef

[3] ASTM F2792-12a, Standard Terminology for Additive Manufacturing Technologies, ASTM International, West Conshohocken, PA, 2012, CrossRef

[4] J.C. Halpin, J.L. Kardos, The Halpin-Tsai equations: A review, Polymer Engineering and Science 16(5), 1976, pp. 344-352, CrossRef

[5] M.D. Nestorović, N.T. llidis, Onset of failure in finitely strained layered composites subjected to combined normal and shear loading, Journal of the Mechanics and Physics of Solids 52(4), 2004, pp. 941-974, CrossRef

[6] ASTM D906-20, Standard Test Method for Strength Properties of Adhesives in Plywood Type Construction in Shear by Tension Loading, ASTM International, West Conshohocken, PA, 2020, CrossRef

[7] ASTM D3528-96, Standard Test Method for Strength Properties of Double Lap Shear Adhesive Joints by Tension Loading, ASTM International, West Conshohocken, PA, 2016, CrossRef

[8] M. Andó, M. Birosz, Sudhanraj Jeganmohan, Surface bonding of additive manufactured parts from multi-colored PLA materials, Measurement 169, 2021, 108583, CrossRef

[9] ASTM B831-19, Standard Test Method for Shear Testing of Thin Aluminum Alloy Products, ASTM International, West Conshohocken, PA, 2019, CrossRef

[10] MIL-STD-1312-13, Fastener test methods: Method 13 - Double Shear Test, Department of Defense - United States of America, Washington DC, 1984. 